\title{
Divided by a Common Language? Transnational Insights into Epistemological and Methodological Approaches to Strategic Management Research in English-Speaking Countries
}

\author{
Alan Pilkington, Thomas C. Lawton
}

In this study, we examine what is important to strategic management researchers in different countries and investigate whether or not there is a demarcation between North American-based scholars and those established elsewhere in the native English-speaking world. We advance data in support of the argument that there is a difference of approach to strategic management research between scholars and leading journals based in North America (USA and Anglophone Canada), compared with the rest of the world. We further argue that this has implications for strategic management teaching and practice. Our analysis of strategy research in the leading journals of the strategic and general management field found that - at a methodological level - North American-based scholars and journals have a quantitative, statistically-driven partiality, whereas scholars and journals based elsewhere in the English-speaking world favor qualitative, case-based research. At an epistemological level, North American research displays a managerialist inclination, concerned with improving the management of organizations. In contrast, research conducted in Australia, Ireland, New Zealand and the UK in particular exhibits a sociological partiality, interested in scrutinizing organizational meaning and social interactions. The implications may be evidenced in a more critical perspective on general management development and practice in these countries, and a performance optimizing approach in North America.

(c) 2013 Elsevier Ltd. All rights reserved.

\section{Introduction}

Management scholars frequently presume that cross-national differences exist in how they approach and analyze the same phenomena. These presumed differences do not arise due to divergent national cultural norms and behaviors. Rather, they are primarily attributable to variations in doctoral program structures and content, and the overall professional training of individual academics. The nature of this perceived disconnect is not always clear. Members of the two largest Englishspeaking management academies - the U.S.-based Academy of Management and the UK-based British Academy of Management - frequently debate whether and why such a divide exists and what can be done to more effectively integrate the international management research community (cf. Tranfield and Starkey, 1998). Common wisdom is that differences stem from disciplinary and methodological origins, with a belief that economics and quantitative methods dominate the U.S. academy, whereas sociology and qualitative approaches pervade in the UK and elsewhere. Consequently, the U.S. school allied for the most part with its North American counterpart in Canada - is more managerialist than its critical theory colleagues in Australia, New Zealand (NZ), Ireland and the UK. ${ }^{1}$ However, these views remain unsubstantiated. Membership of the respective academies does illustrate a geographical divide, which may reflect a difference of approach, both conceptually and methodologically. Official academy figures show that in 2013, 60 percent of the 18,477 active members of the Academy of Management (AoM) were from the U.S. and Canada, with 5 percent from the UK and Ireland (AoM, 2013). Even with Australia and New Zealand included, this value does not exceed 9 percent. For the British Academy of Management (BAM), membership is highly focused on the UK, with 79 percent of the 1677 members in 2013 from the British Isles and only 1 percent from North America (BAM, 2013).

\footnotetext{
1 It is important to note that an epistemological and methodological shift is occurring in some non-North American Anglophone countries and territories with active and growing strategy research communities. In particular, business schools in Hong Kong and Singapore would traditionally have looked to the British model but that appears to be changing rapidly. Reinforced by a revised rewards system, faculty in these schools now primarily target U.S. journals and carry out research in the U.S. style. Although still nascent, a similar trend is developing in leading Australian and British business schools.
} 
In this paper, we employ bibliographic citation and co-citation analyses to compare and contrast the research agendas and outputs relating to strategic management in the leading strategic management and general management journals. These include the primary journals affiliated with the U.S. and UK academies of management. Due to its increasing prominence in Academy of Management Journal (AMJ) and British Journal of Management (BJM) discourse and publication, we are particularly interested in contrasting approaches to the study of strategic management. Despite common business models and much interaction across the years, the ways that management research is approached in U.S. business schools is often perceived as divergent with elsewhere in the English-speaking world. But does this divergence actually exist? In order to investigate the nature and veracity of this perception, we undertake a bibliometric-driven analysis of the strategic management related work in the ten most-cited and highly ranked publications in the strategic and general management field. These are Academy of Management Journal (AMJ), Academy of Management Review (AMR), Administrative Science Quarterly (ASQ), Advances in Strategic Management (ASM), British Journal of Management (BJM), Journal of Economics E Management Strategy (JEMS), Journal of Management (JM), Journal of Management Studies (JMS), Long Range Planning (LRP) and Strategic Management Journal (SMJ). Of these, as of 2013, two are affiliated with the U.S.-based Academy of Management and have North American-based and/or trained editors (AMJ and AMR), and four others have U.S.-based editors (ASQ JEMS, JM and SMJ). The book series, ASM, has a Canadian-based editor; LRP's editor is based in Austria; BJM is affiliated with the British Academy of Management and has a UK-based editor; and, JMS has a global editorial team spanning Australia, the U.S., Europe and Singapore.

Concentrating only on peer-reviewed journals, and therefore omitting the ASM book series, we argue that there is a fundamental difference in style and substance between the first six journals (which we classify as North American-based) and the last three journals (classified as rest of the world or international). Although not conclusive or exclusive, and acknowledging the preponderance of North American-based journals, this reflects a difference of approach to management research, particularly in strategic management. At a methodological level, journals such as AMJ, ASQ and SMJ have a quantitative, statistically-driven bias, whereas BJM, JMS and LRP lean heavily towards qualitative, case-based research. At an epistemological level, the North American-based journals display a managerialist inclination, concerned with what we can learn to improve the management of organizations. In contrast, the international journals exhibit a sociological partiality, interested in scrutinizing meaning and social interactions in complex organizations. The impact implications are likely to be significant, evidenced in a more critical perspective on management development and practice in countries like Australia or the UK, and a performance-optimizing approach in Canada and the U.S. Further research may reveal how much and in what ways this methodological and epistemological partition has real impact on respective approaches to management teaching, executive education and consulting.

\section{Review of methodology}

An objective approach to tackling the intellectual structure of the field is through citation and co-citation studies studying the articles actually cited in research studies - to reveal the structure of the interrelationships among articles. This relies on patterns in the works that are commonly cited together. Using citation analysis, we can examine the growth in citations and get a sense of when the major articles in the field were written, how article popularity fared over time, and whether an article is still useful to current researchers. An article that continues to be cited indicates its historic value over time as well as its role in supplemental studies. We can also use the citations to determine changes in field direction, whether alternative journals refer to the same literature, and whether the journals themselves change focus.

However, there can be dangers in using citations to make inferences. Garfield (1979) identifies a number of issues, such as using first authors rather than all authors, which leads to missing important contributions from secondary and later authors. This was especially relevant in an era of the hard copy Social Science Citation Index. The advent of electronic indexing has made the tracking of second authors much easier. Moreover, the unit of analysis in this paper is not the people who contribute to the field, but the whole publication. There is also a problem in identifying the correct data (person, journal or book) when dealing with similar names. Here we have limited the impact of this problem by carefully selecting the source documents, and also by screening. For example, different data sources and journals often adopt differing citation styles, and so the same journal or author may be listed differently, as a result of abbreviations and full name, one initial, or multiple initials. Books are also a problem as they are published in multiple editions. Negative citations - citing a reference as a bad example of practice and self-citations are often given as a source of confusion in citation analysis. Here we believe that negative citation is too slight to worry about and the self-citations limited, as we draw on the contents of many journals. Another concern raised by Garfield is treating methodological and findings papers equally, but as we are equally interested in both, this is not seen as a problem. A further topic often of concern is how to weight the contributions identified. In our study, we believe that equal value should be applied to each work as we seek to describe the evolution of the field from two perspectives.

Leydesdorff and Vaughan (2006), as an alternative to citation analysis, examine the information to be obtained using cocitation analysis and describe publications as "texts". They argue that co-citation data can be considered linkage data among texts, while cited references are variables attributed to texts. Analyzing co-citation network patterns using tools such as factor analysis provides groupings in a field, and also allows us to plot how they change with the journal over time. Similarly, other tools can be used to graphically plot citation influence; how they relate; the strength of relationships; and, how central to groups a citation is. Thus, co-citation analysis allows not only a view of importance but also the relationships in the 
intellectual structure of the field. So co-citation studies show the topics, themes, and research methods in a field, and how they may have changed over time.

With regards to the objective of this study - assessing whether a selection of North American and non-North American based scholars are interested in the same issues and deploy the same approaches when dealing with strategic management we follow in the footsteps of Usdiken and Pasadeos (1995), and Pilkington and Liston-Heyes (1999). Usdiken and Pasadeos (1995) tested the literature of organizational analysis for a similar geographical division. They found that two of the major journals in management and organization studies, the North American edited Administrative Science Quarterly and the European edited Organization Studies, almost exclusively published the work of local authors who were similarly parochial in their citation practices. Pilkington and Liston-Heyes (1999) analyzed the operations management literature represented by the International Journal of Operations and Production Management (IJOPM) and found a difference in the research agenda of the North American and European contingents and how such discrepancies may have hindered the establishment of OM as a legitimate discipline by blurring the boundaries of its literature. Europeans were shown to have a much greater interest in Japan, although this may or may not imply that North Americans do not share their interest in Japanese techniques per se, but may have integrated the concepts with other examples and strategies. More recently, this work has been extended to investigate the evolution of all the citations of the entire field represented by the three operations management journals right from their inception (Pilkington \& Meredith, 2009).

\section{Methodology and data}

In this paper we utilize objective, quantitative techniques such as bibliographic citation and co-citation analyses to study differences between specific North American and non-North American management research outputs in strategy and comment on the implications. Citation analysis relies on the idea that a heavily cited article will have exerted a greater influence on a subject than those less frequently referenced (Culnan, 1986; Sharplin and Mabry, 1985) and will represent more activity or importance in the field. While this assumption has some weaknesses as outlined above, given adequate screening and a large enough sample, citation analysis provides a useful insight into which journals, papers, and authors are considered influential. According to White and Griffith (1990), citation analysis represents the field's view of itself. As an example, Vokurka (1996) used citation analysis to determine the journals most important to the field of OM, which is of interest to academics not least for promotion and tenure decisions.

However, citation analysis does not show the structure of ideas in a field (Leong, 1989). This can be achieved with the addition of co-citation analysis, which is able to identify the relationships among the articles identified through citation analysis. Here the authors, topics, journals, keywords, or even research methods, can be plotted and the structural groupings of these relationships identified. Studying co-citations also shows how the groups relate to each other (Small, 1973). White (1990, p. 99) notes that co-citation analysis reveals the intellectual structure of scholarly fields, and recommends "nothing better for reconnoitering 'macro-level' intellectual structure as it evolves... The maps are essentially a new kind of graphics for revealing inter-textual relationships." In reporting the relationships with cocitations, several approaches are often used, including using factor analysis or multi-dimensional scaling (MDS) to identify implicit dimensions. Factor analysis was used, for example, by Pilkington and Meredith (2009) to identify that the most-cited articles in operations management could fit into twelve groups and so repeatedly cover these topics. MDS examples include Ramos-Rodríguez and Ruíz-Navarro (2004) and Hoffman and Holbrook (1993), who use this approach to represent the structural knowledge of the strategic management and consumer research disciplines. Another approach is to utilize network analysis tools to represent the information, and also develop measures that allow comparisons between different networks (in different disciplines or from alternative sources) and the roles of the nodes (authors or articles) themselves. These techniques have been employed to examine the development of a range of disciplines, including service and technology management (Pilkington and Chai, 2008; Pilkington and Teichert, 2006).

One of the key dimensions of bibliometrics is identifying appropriate articles for inclusion in the study and ensuring that they represent the area of investigation well. Often a panel of experts identifies the prominent authors in a given field and this is then used as a basis from which to expand the search, usually by retrieving papers that cite any of their articles. This set of papers is then subjected to analysis using the cited author level with authors acting as a proxy for their ideas and contributions. In our study, we are fortunate in that using an established list of top-rated strategy-focused journals, and also the strategy-related articles in the top-rated general management titles, as the source population allows us to perform the analysis at the individual publication level. This gives a more detailed representation of topics discussed than a standard author citation analysis, which is particularly valuable as authors in a tightly defined field often make repeated contributions in a range of areas. Such detailed citation/co-citation studies have been employed in areas close to strategic management and in particular to examine differences between groups of scholars. Examples include the previously cited work of Usdiken and Pasadeos (1995) and Pilkington and Liston-Heyes (1999).

The normal source of bibliometric data for studies is the ISI Social Science Citations Index, which contains both information on source articles and their citation lists. We used this as the source for our data for this study. Specifically, the data used in the study reported on here included the contents of the previously listed journals between 2000 and 2010, as recorded in the ISI Social Science Citation Index. The entire content of the strategy-focused journals was studied, along with those articles from the general management titles that featured a truncated keyword of "STRAT" or "COMPET" to capture their 
contributions to the field. As we proceed with the results and analysis, we will explore whether these journals are able to substantiate the geographical division we are seeking to test in the research question. In addition, we identified the country of the first author of each article and used this to label them as following either the North American tradition: USA and Canada; the British tradition: UK, Ireland, Australia and New Zealand; or, the rest of the World.

Several steps are required to start working with ISI data, including converting into a standard format and checking for different spellings and abbreviations of names, journal and book titles, as well as book editions. To try to reduce these ISI inconsistencies as far as possible, we adopted a process of manually checking and re-checking ranked frequency tables of separate and combined data fields and using complex search and replace routines to generate standardized records. In practice, this involves generating frequency tables of the different fields, both in isolation and then combined, and examining whether there are similar entries to the high frequency terms which should be adjusted. For example, ACAD_MANAGE_J (Academy of Management Journal) was one of the most-listed titles, and so corresponding entries such as AC_MANAGE_J and ACAD_MANAG_J were altered. As such, our data contains the source article information such as publication information, authors, titles, and keywords, cross-linked to their standardized citations. As explained above, the level of information contained in the standardized citations was first author (with one initial), publication (journal or book title) and publication year. Due care was taken to double check that information was not amalgamated when removing author initials and publication issue information. Standardization of book editions into one single reference was accomplished using a similar frequency check approach.

We acknowledge that there are limitations to our study in terms of the choice and number of journals analyzed, the extraction of articles from the general management titles, and the extent to which extrapolation is feasible. As a consequence, we emphasize that our findings are indicative rather than conclusive.

\section{Results}

Table 1 shows the countries of origin of the authors identified for correspondence for the source articles from the data. The data are an aggregate of our ten-year period of focus. There are clear geographical divisions between the journals, with North American-based authors being the dominant contributors to AMJ, AMR, ASQ JEMS, JM and SMJ (as well as to the ASM book series); and non-North American (UK, Australia, Ireland and New Zealand, plus rest of the world) based authors the major writers of articles for BJM, JMS and LRP. This shows that the division between the journals reflects, as expected, a dichotomy between North American and non-North American based authors. Also it is valuable for this study to note the limited degree of cross publishing between the groups.

\section{Citation data}

We have established that there is and remains a clear geographical division between the authors who publish in specific journals. As we are concerned with citation information for the rest of the analysis, we examined whether there is any difference in the general citation behavior between authors from different traditions. One simple way to examine whether the author groups show different citation habits is to look at the age of the citations. Table 2 gives the mean age of citation in each group as around twelve years. This twelve year peak has also been seen in other studies (Pilkington and Meredith, 2009; Ramos-Rodríguez and Ruíz-Navarro, 2004), which also report a growth of about 2.3 citations/journal/year up to an average of 28 after twelve years, and a variation in citation rates reaching a maximum of four times the average for popular articles (Stremersch et al., 2007). Table 2 also reports a two means z-test statistic to see if the slight difference between the geographical origins of authors is significant. The z-value shows that there is no evidence to suggest that the author groups have different practices in their citing with regards to the spread of age of citations.

Now that we have established that the two groups of authors do not differ in terms of the nature of their citations, we can start to analyze if there are distinct areas covered which classify the two spheres of management study we are concerned with. Table 3 focuses on the 40 most-frequently cited publications (including ties for the last entries) among the journals over

Table 1

Country of authors publishing in the source journals

\begin{tabular}{|c|c|c|c|}
\hline & North America & Australia/Ireland/NZ/UK & Rest of world \\
\hline ACAD MANAGE J & $79.70 \%$ & $3.96 \%$ & $16.34 \%$ \\
\hline ACAD MANAGE REV & $72.50 \%$ & $10.83 \%$ & $16.67 \%$ \\
\hline ADMIN SCI QUART & $89.80 \%$ & $2.04 \%$ & $8.16 \%$ \\
\hline ADV STRAT M & $70.63 \%$ & $6.99 \%$ & $22.38 \%$ \\
\hline BRIT J MANAGE & $17.05 \%$ & $39.77 \%$ & $43.18 \%$ \\
\hline J ECON MANAGE STRAT & $55.96 \%$ & $6.74 \%$ & $37.31 \%$ \\
\hline J MANAGE & $80.56 \%$ & $2.08 \%$ & $17.36 \%$ \\
\hline J MANAGE STUD & $38.76 \%$ & $25.84 \%$ & $35.41 \%$ \\
\hline LONG RANGE PLANN & $27.52 \%$ & $24.31 \%$ & $48.17 \%$ \\
\hline STRATEG MANAGE J & $76.07 \%$ & $5.08 \%$ & $18.85 \%$ \\
\hline Grand Total & $63.48 \%$ & $10.79 \%$ & $25.73 \%$ \\
\hline
\end{tabular}


Table 2

Differences in age of citation between author groups (z-test: two sample for means)

\begin{tabular}{lll}
\hline & North American & Australia/Ireland/NZ/UK \\
\hline Mean & 13.1 & 12.5 \\
Known variance & 218.2137 & 119.1478 \\
Observations & 94955 & 17786 \\
Hypothesized no difference in mean: & $\mathrm{P}(\mathrm{Z} \leq \mathrm{z})$ two-tail & $4.52569 \mathrm{E}-11$ \\
\hline
\end{tabular}

the ten years of this study and their resulting frequencies. Since the journals publish a different number of papers each year, the values are also given as basis points; that is, reference citations per 10,000 citations. Hence, the most-frequently cited reference by both sets of authors, for instance, is Barney's paper on the resource-based view (RBV), which is cited 56 times by Australia/Ireland/NZ/UK authors in total, or 32.1 times for every 10,000 citations; and 326 times or 35.16 times per 10,000 citations by North Americans. Despite the importance of journals in the field, many of the most popular citations are books rather than research articles. This pattern has also been found in other studies on strategic management (Ramos-Rodríguez and Ruíz-Navarro, 2004) and also on the relatively new field of operations management (Pilkington and Meredith, 2009). Using the table, it is possible to see how the most popular publications differ between the different groups. Our interpretation here is that they have many similarities in terms of core ideas, but they appear to deal with the topics in different ways. Looking at Table 3 for differences, notable is the presence of methodological citations. For example, the second most cited source by Australia/Ireland/NZ/UK authors is Eisenhardt's justification of case methodology, a theme that is also supported by

Table 3

The most cited publications by authors from each tradition

\begin{tabular}{|c|c|c|c|c|c|}
\hline \multicolumn{3}{|l|}{ Australia/Ireland/NZ/UK } & \multicolumn{3}{|l|}{ North America } \\
\hline & Frequency & $\begin{array}{l}\text { Rate per } \\
\text { 10k citations }\end{array}$ & & Frequency & $\begin{array}{l}\text { Rate per } \\
10 \mathrm{k} \text { citations }\end{array}$ \\
\hline BARNEY_J,J_MANAGE,1991 & 56 & 32.10 & BARNEY_J,J_MANAGE,1991 & 326 & 35.16 \\
\hline EISENHARDT_K,ACAD_MANAGE_REV,1989 & 33 & 18.92 & NELSON_R,EVOLUTIONARY_THEORY,1982 & 237 & 25.56 \\
\hline PORTER_M,COMPETITIVE_STRATEGY,1980 & 27 & 15.48 & COHEN_W,ADMIN_SCI_QUART,1990 & 199 & 21.46 \\
\hline DIERICKX_I,MANAGE_SCI,1989 & 27 & 15.48 & PORTER_M,COMPETITIVE_STRATEGY,1980 & 195 & 21.03 \\
\hline PENROSE_E,THEORY_GROWTH_FIRM,1959 & 26 & 14.90 & CYERT_R,BEHAV_THEORY_FIRM,1963 & 179 & 19.31 \\
\hline WILLIAMSON_O,EC_I_CAPITALISM,1985 & 25 & 14.33 & DIERICKX_I,MANAGE_SCI,1989 & 176 & 18.98 \\
\hline NELSON_R,EVOLUTIONARY_THEORY,1982 & 24 & 13.76 & WILLIAMSON_O,EC_I_CAPITALISM,1985 & 168 & 18.12 \\
\hline COHEN_W,ADMIN_SCI_QUART,1990 & 24 & 13.76 & MARCH_J,ORGAN_SCI,1991 & 163 & 17.58 \\
\hline DIMAGGIO_P,AM_SOCIOL_REV,1983 & 22 & 12.61 & PFEFFER_J,EXTERNAL_CONTROL_ORG,1978 & 157 & 16.93 \\
\hline WILLIAMSON_O,MARKETS_HIERARCHIES,1975 & 21 & 12.04 & DIMAGGIO_P,AM_SOCIOL_REV,1983 & 153 & 16.50 \\
\hline PETERAF_M,STRATEG_MANAGE_J,1993 & 18 & 10.32 & PENROSE_E,THEORY_GROWTH_FIRM,1959 & 149 & 16.07 \\
\hline STRAUSS_A,BASICS_QUALITATIVE_R,1990 & 18 & 10.32 & PETERAF_M,STRATEG_MANAGE_J,1993 & 147 & 15.86 \\
\hline MEYER_J,AM_J_SOCIOL,1977 & 18 & 10.32 & KOGUT_B,ORGAN_SCI,1992 & 142 & 15.32 \\
\hline HAMBRICK_D,ACAD_MANAGE_REV,1984 & 18 & 10.32 & WILLIAMSON_O,MARKETS_HIERARCHIES,1975 & 140 & 15.10 \\
\hline CYERT_R,BEHAV_THEORY_FIRM,1963 & 17 & 9.74 & DYER_J,ACAD_MANAGE_REV,1998 & 120 & 12.94 \\
\hline PORTER_M,COMPETITIVE_ADV_CREA,1985 & 17 & 9.74 & JENSEN_M,J_FINANC_ECON,1976 & 112 & 12.08 \\
\hline MARCH_J,ORGAN_SCI,1991 & 17 & 9.74 & TEECE_D,RES_POLICY,1986 & 111 & 11.97 \\
\hline THOMPSON_J,ORG_ACTION,1967 & 16 & 9.17 & GREENE_W,ECONOMETRIC_ANAL,1993 & 110 & 11.86 \\
\hline PRAHALAD_C,HARVARD_BUS_REV,1990 & 15 & 8.60 & BARNEY_J,MANAGE_SCI,1986 & 108 & 11.65 \\
\hline GLASER_B,DISCOVERY_GROUNDED_T,1967 & 15 & 8.60 & GRANOVETTER_M,AM_J_SOCIOL,1985 & 108 & 11.65 \\
\hline JENSEN_M,J_FINANC_ECON,1976 & 15 & 8.60 & THOMPSON_J,ORG_ACTION,1967 & 105 & 11.33 \\
\hline YIN_R,CASE_STUDY_RES,1994 & 14 & 8.03 & LEVINTHAL_D,STRATEG_MANAGE_J,1993 & 101 & 10.89 \\
\hline WEICK_K,SENSEMAKING_ORG,1995 & 14 & 8.03 & GULATI_R,ACAD_MANAGE_J,1995 & 99 & 10.68 \\
\hline HUBER_G,ORGAN_SCI,1991 & 14 & 8.03 & LEVITT_B,ANNU_REV_SOCIOL,1988 & 98 & 10.57 \\
\hline RUMELT_R,COMPETITIVE_STRATEGY,1984 & 14 & 8.03 & LANE_P,STRATEG_MANAGE_J,1998 & 98 & 10.57 \\
\hline EISENHARDT_K,STRATEG_MANAGE_J,2000 & 14 & 8.03 & PORTER_M,COMPETITIVE_ADV_CREA,1985 & 98 & 10.57 \\
\hline ZOLLO_M,ORGAN_SCI,2002 & 14 & 8.03 & HENDERSON_R,ADMIN_SCI_QUART,1990 & 96 & 10.35 \\
\hline PRIEM_R,ACAD_MANAGE_REV,2001 & 13 & 7.45 & POWELL_W,ADMIN_SCI_QUART,1996 & 95 & 10.25 \\
\hline DYER_J,ACAD_MANAGE_REV,1998 & 13 & 7.45 & HAMBRICK_D,ACAD_MANAGE_REV,1984 & 95 & 10.25 \\
\hline HAIR_J,MULTIVARIATE_DATA_AN,1995 & 13 & 7.45 & AIKEN_L,MULTIPLE_REGRESSION,1991 & 94 & 10.14 \\
\hline BURT_R,STRUCTURAL_HOLES,1992 & 13 & 7.45 & BURT_R,STRUCTURAL_HOLES,1992 & 92 & 9.92 \\
\hline GRANT_R,STRATEG_MANAGE_J,1996 & 13 & 7.45 & HANNAN_M,AM_SOCIOL_REV,1984 & 92 & 9.92 \\
\hline BARNEY_J,ACAD_MANAGE_REV,1986 & 12 & 6.88 & TUSHMAN_M,ADMIN_SCI_QUART,1986 & 91 & 9.82 \\
\hline MILES_M,QUALITATIVE_DATA_ANA,1984 & 12 & 6.88 & EISENHARDT_K,STRATEG_MANAGE_J,2000 & 89 & 9.60 \\
\hline MARCH_J,ORGANIZATIONS,1958 & 12 & 6.88 & GRANT_R,STRATEG_MANAGE_J,1996 & 87 & 9.38 \\
\hline GRANOVETTER_M,AM_J_SOCIOL,1973 & 12 & 6.88 & AMIT_R,STRATEG_MANAGE_J,1993 & 86 & 9.28 \\
\hline PETERS_T,SEARCH_EXCELLENCE,1982 & 12 & 6.88 & PRAHALAD_C,HARVARD_BUS_REV,1990 & 84 & 9.06 \\
\hline KOGUT_B,ORGAN_SCI,1992 & 12 & 6.88 & EISENHARDT_K,ACAD_MANAGE_REV,1989 & 84 & 9.06 \\
\hline LEONARDBARTON_D,STRATEG_MANAGE_J,1992 & 12 & 6.88 & HANNAN_M,ORG_ECOLOGY,1989 & 84 & 9.06 \\
\hline JOHNSON_G,J_MANAGE_STUD,2003 & 12 & 6.88 & MARCH_J,ORGANIZATIONS,1958 & 83 & 8.95 \\
\hline
\end{tabular}


Yin's book further down the list. Similarly, the books on grounded theory feature high on the list (Strauss and Corbin and Glaser and Strauss) but do not appear in the top list for North Americans. There is also a related inclusion in the North American list of quantitative methodologies including Greene on econometric analysis and Aiken and West's book on multiple regressions.

As Table 3 illustrates, one general aspect to note is that the North American derived citations appear more homogenous than the Australia/Ireland/NZ/UK for instance, in that the scores for the most cited items are higher, even after adjusting for the different number of articles published in each group (the per 10,000 basis point values). We can analyze this with the Herfindahl-Hirschman Index (HHI) that is normally used to compare the level of competition in different industries by assessing the importance of the main players. The HHI for the citation frequency results of the two groups are: North American: 0.000177, and Australia/Ireland/NZ/UK: 0.000114, showing that the most cited articles from North America are proportionally more cited than they are by the other. Our conclusion is either that the predominantly North American-based authors have a clearer, more focused notion of the foundations of management, or that the practice of identifying previous work and locating the research in a field demands a set routine for North Americans. In comparison, non-North American based authors need only to draw on a narrower description to locate their contribution. In the next co-citation subsection, we examine data for each of the journals to find the significant differences between their citation behavior, and we analyze the intellectual structure dynamics of the field more directly.

Co-citation results

In addition to analyzing the rates of references of the articles published in the journals we can determine if any two references are commonly referenced together, or co-cited. If some references are frequently co-cited, then this represents a structural knowledge grouping. Identifying these groupings and the relationships between and among them describes the intellectual structure of a field.

To examine the major structural knowledge groupings, we performed principal component factor analysis on the cocitation matrix, a common practice in bibliometrics (White and McCain 1998). The results for each author group are presented in Tables 4 and 5, with Table 4 focusing on factor groupings for North America and Table 5 focusing on non-North American factor groupings (illustrated by Australia/Ireland/NZ/UK). The principal component analysis was conducted in SPSS and involved the analysis of the correlation matrix calculated from the co-citations of the top 50 citations for each journal. In order to give a better chance at reliable results, we followed the advice of Hair (1995) who recommends analyzing a matrix with five times as many records as variable and so calculated the correlation of the top 50 references to the top 500 references as a matrix. We then reduced the 50 references into their underlying dimensions based on how they relate to each other and the similarities of their relationships to the next 450 references as well.

The use of various measures of similarity, dissimilarity, and correlation in performing multidimensional analysis of cocitation data is the source of some discussion (Bensman 2004). However, Leydesdorff (1987) and Leydesdorff and Vaughan (2006, p. 1624) explain that while this may have an impact on weak MDS relationship representations, "by rotating the matrix, factor analysis enables us to retrieve the underlying structure despite the assumptions made about normality in the distribution," and obtains "a higher-dimensional and quantitative understanding of the structures underlying these geometrical representations."

We therefore employed the recommended varimax rotation, as this attempts to fit (or load) the maximum number of documents on the minimum number of factors. The Kaiser-Meyer-Olin measure of sampling adequacy for the matrices was very suitable. Similarly, Bartlett's test was significant at a p of less than 0.001 for both journal sets, which indicates that principal components analysis was suitable. Based on a scree test, four factors were extracted for each set, which explained over 54 and 74 percent of the variance in each correlation matrix and is considered to be reasonable (Field, 2000).

By examining the topics of the citations included within the factors (which score greater than 0.4 loadings), the knowledge groupings being captured by each of the factors were clear and the factors were named accordingly. Again we followed accepted advice in examining the loading values as Hair (1995) recommends that a factor loading of \pm 0.3 means the item is of minimal significance, \pm 0.4 indicates more importance, and \pm 0.5 indicates the factor is significant (Hair, 1995). Hence Tables 4 and 5 show factor loadings of greater than 0.4 .

One notable finding is that both sets of authors largely agree on the core issues in strategic management. As reported in Tables 4 and 5, for each group Factor 1 is very similar and focuses on the Penrosian-derived resource-based view (RBV) of the firm. The theoretical foundations of the RBV (Penrose, 1959; Rumelt, 1984; Wernerfelt, 1984; Barney, 1986, 1991; Dierickx and Cool, 1989; Peteraf, 1993; Teece, 1997) are commonly cited. However, there are subtle differences in conceptual and methodological approach evidenced in Factor 1, particularly the Australia/Ireland/NZ/UK loading attributed to Zollo and Winter (2002) and Eisenhardt (1989).

The literature in the second factor from the North Americans is similar to the third for Australia/Ireland/NZ/UK as they relate to organizational learning for advantage. One significant difference is the way the North American group have a positivist focus as seen in the organizational myopia and organizational learning articles; whilst the Australia/Ireland/NZ/UK focus is more on understanding the internal mechanisms, with the focus on the Cyert-March duopoly model.

Again we see similarities but also subtle differences when we compare the North American third factor (Table 4 ) to Factor 2 in Table 5. Both deal with the value of ties and networks, as can be seen by Granovetter and Burt on structural holes. But the North Americans display a positivist leaning in their focus on Gulati's work on network ties as a source of alliance. The third 
Table 4

Factor groupings North America

\begin{tabular}{|c|c|c|c|c|}
\hline & 1: Resource-based view & $\begin{array}{l}\text { 2: Organizational } \\
\text { learning for } \\
\text { advantage }\end{array}$ & $\begin{array}{l}\text { 3: Positivist } \\
\text { network approach }\end{array}$ & $\begin{array}{l}\text { 4: Quantitative } \\
\text { research }\end{array}$ \\
\hline BARNEY J, MANAGE SCI,1986 & 0.911 & & & \\
\hline AMIT R, STRATEG MANAGE J,1993 & 0.906 & & & \\
\hline PETERAF M, STRATEG MANAGE J,1993 & 0.896 & & & \\
\hline PENROSE E, THEORY GROWTH FIRM,1959 & 0.874 & & & \\
\hline DIERICKX I, MANAGE SCI,1989 & 0.874 & & & \\
\hline WERNERFELT B, STRATEG MANAGE J,1984 & 0.871 & & & \\
\hline PRAHALAD C, HARVARD BUS REV,1990 & 0.865 & & & \\
\hline TEECE D, STRATEG MANAGE J,1997 & 0.819 & & & \\
\hline BARNEY J, J MANAGE,1991 & 0.8 & & & \\
\hline PORTER M, COMPETITIVE ADV CREA, 1985 & 0.787 & & & \\
\hline EISENHARDT K, STRATEG MANAGE J,2000 & 0.785 & 0.411 & & \\
\hline GRANT R, STRATEG MANAGE J,1996 & 0.759 & 0.401 & & \\
\hline TEECE D, RES POLICY,1986 & 0.722 & 0.426 & & \\
\hline PORTER M, COMPETITIVE STRATEGY, 1980 & 0.721 & & & \\
\hline KOGUT B, ORGAN SCI,1992 & 0.702 & 0.442 & & \\
\hline NELSON R, EVOLUTIONARY THEORY,1982 & 0.665 & 0.538 & & \\
\hline WILLIAMSON O, MARKETS HIERARCHIES, 1975 & 0.652 & & 0.503 & \\
\hline COHEN W, ADMIN SCI QUART,1990 & 0.583 & 0.561 & 0.401 & \\
\hline THOMPSON J, ORG ACTION,1967 & 0.449 & & & \\
\hline LEVINTHAL D, STRATEG MANAGE J,1993 & & 0.811 & & \\
\hline LEVITT B, ANNU REV SOCIOL, 1988 & & 0.768 & & \\
\hline MARCH J, ORGAN SCI,1991 & 0.413 & 0.76 & & \\
\hline HENDERSON R, ADMIN SCI QUART,1990 & 0.509 & 0.728 & & \\
\hline TUSHMAN M, ADMIN SCI QUART,1986 & 0.501 & 0.683 & & \\
\hline CYERT R, BEHAV THEORY FIRM,1963 & & 0.63 & & \\
\hline HANNAN M, AM SOCIOL REV,1984 & & 0.612 & & \\
\hline GREENE W, ECONOMETRIC ANAL,1993 & & 0.469 & & 0.421 \\
\hline GULATI R, ACAD MANAGE J,1995 & & & 0.89 & \\
\hline GRANOVETTER M, AM J SOCIOL,1985 & & & 0.864 & \\
\hline POWELL W, ADMIN SCI QUART,1996 & & & 0.829 & \\
\hline DYER J, ACAD MANAGE REV,1998 & 0.403 & & 0.823 & \\
\hline BURT R, STRUCTURAL HOLES, 1992 & & & 0.75 & \\
\hline WILLIAMSON O, EC I CAPITALISM,1985 & 0.486 & & 0.651 & \\
\hline LANE P, STRATEG MANAGE J,1998 & 0.413 & 0.451 & 0.591 & \\
\hline AIKEN L, MULTIPLE REGRESSION,1991 & & & 0.528 & 0.453 \\
\hline JENSEN M, J FINANC ECON,1976 & & & & 0.857 \\
\hline EISENHARDT K, ACAD MANAGE REV,1989 & & & & 0.728 \\
\hline HAMBRICK D, ACAD MANAGE REV,1984 & & & & 0.591 \\
\hline
\end{tabular}

factor also includes Powell, Koput and Smith-Doerr's work on biotech networks of learning and an emphasis on a multiple regression approach. In comparison, the Australia/Ireland/NZ/UK approach has a sociological leaning towards the ideas of Cohen and Levinthal on absorptive capacity and learning, Kogut and Zander on the internal mechanism sharing and transfer of knowledge, and Szulanski on internal stickiness.

The final factor is not a management topic itself but rather a group concerned with the case study method and qualitative research (Miles and Huberman, 1994; Yin, 1994; Strauss, 1990). We were surprised to see this present without a clear grouping on quantitative research techniques for the North Americans, given our view of their propensity to use the survey and SEM approaches. We believe the emergence of a clear and significant qualitative group is probably a reflection on the methodology itself in management research, whereas quantitative studies are developed to such a degree that the references contained are to other similar studies and not the fundamentals of the methodology itself.

The final North American factor in Table 4 is about ownership and accountability, (Jensen and Meckling, 1976), and Hambrick and Mason on the background of top managers. The inclusion of the Eisenhardt paper may be puzzling but could be explained as it is quite a marginal factor score for inclusion. It not only discusses theory from case method but also includes an example (Table 3, p. 543) of a CEO power construct measure.

\section{Co-citation network illustrations}

To analyze the structure of interactions between the co-citations representing the various factors, we drew networks of the citations that constitute the various factors. The results are shown in Figures 1 and 2 for North American based and Australia/Ireland/NZ/UK based authors respectively.

There are several alternative methods to illustrate the co-citation linkages between the references (nodes) and so represent the various structural knowledge groupings. Ramos-Rodríguez and Ruíz-Navarro (2004) and Hoffman and 
Table 5

Factor groupings Australia/Ireland/NZ/UK

\begin{tabular}{|c|c|c|c|c|}
\hline & 1: Resource based view & $\begin{array}{l}\text { 2: Sociology of } \\
\text { networks }\end{array}$ & $\begin{array}{l}\text { 3: Organisational } \\
\text { learning }\end{array}$ & 4: Qualitative method \\
\hline PETERAF M, STRATEG MANAGE J,1993 & 0.911 & & & \\
\hline RUMELT R, COMPETITIVE STRATEGY,1984 & 0.887 & & & \\
\hline WERNERFELT B, STRATEG MANAGE J,1984 & 0.873 & & & \\
\hline DIERICKX I, MANAGE SCI,1989 & 0.867 & & & \\
\hline PENROSE E, THEORY GROWTH FIRM,1959 & 0.857 & & & \\
\hline TEECE D, STRATEG MANAGE J,1997 & 0.836 & & & \\
\hline BARNEY J, J MANAGE,1991 & 0.821 & & & \\
\hline PORTER M, COMPETITIVE STRATEGY,1980 & 0.797 & & & \\
\hline EISENHARDT K, STRATEG MANAGE J,2000 & 0.781 & & 0.441 & \\
\hline PRAHALAD C, HARVARD BUS REV,1990 & 0.773 & & & \\
\hline PORTER M, COMPETITIVE ADV CREA,1985 & 0.725 & & & \\
\hline NELSON R, EVOLUTIONARY THEORY,1982 & 0.674 & & 0.525 & \\
\hline GRANT R, STRATEG MANAGE J,1996 & 0.667 & 0.526 & & \\
\hline ZOLLO M, ORGAN SCI,2002 & 0.659 & & 0.547 & \\
\hline LEONARDBARTON D, STRAT MANAGE J,1992 & 0.653 & & & \\
\hline WILLIAMSON O, EC I CAPITALISM,1985 & 0.618 & & & \\
\hline WILLIAMSON O, MARKETS HIERARCHIES,1975 & 0.576 & & & \\
\hline GRANOVETTER M, AM J SOCIOL,1973 & & 0.793 & & \\
\hline BURT R, STRUCTURAL HOLES,1992 & & 0.789 & & \\
\hline DYER J, ACAD MANAGE REV,1998 & & 0.756 & & \\
\hline COHEN W, ADMIN SCI QUART,1990 & & 0.644 & 0.408 & \\
\hline KOGUT B, ORGAN SCI,1992 & 0.465 & 0.569 & 0.469 & \\
\hline SZULANSKI G, STRATEG MANAGE J,1996 & & 0.538 & 0.413 & \\
\hline HUBER G, ORGAN SCI,1991 & & 0.49 & & \\
\hline MARCH J, ORGAN SCI,1991 & & & 0.739 & \\
\hline MARCH J, ORGANIZATIONS, 1958 & & & 0.664 & \\
\hline CYERT R, BEHAV THEORY FIRM,1963 & & & 0.623 & \\
\hline THOMPSON J, ORG ACTION,1967 & & & 0.593 & \\
\hline YIN R, CASE STUDY RES,1994 & & & & 0.761 \\
\hline MILES M, QUALITATIVE DATA ANA,1984 & & & & 0.731 \\
\hline GLASER B, DISCOVERY GROUNDED T,1967 & & & & 0.731 \\
\hline STRAUSS A, BASICS QUALITATIVE R,1990 & & & & 0.725 \\
\hline EISENHARDT K, ACAD MANAGE REV,1989 & 0.416 & & & 0.592 \\
\hline
\end{tabular}

Holbrook (1993) used MDS to represent the structural knowledge of their studies and we could have followed suit with our study but there is a difficulty in showing our multiple underlying factors in two-dimensions. These difficulties were experienced by Culnan (1986), as described by Leydesdorff and Vaughan (2006). We decided to follow the lead of Pilkington and Meredith (2009) and display the results graphically using the techniques developed for social network analysis (Wasserman, 1994; Scott, 1995). The resulting diagrams were produced using NETDRAW part of the UCINET SNA package (Borgatti et al., 2002). NETDRAW is one standard tool for graph mapping along with PAJEK.

The illustrations in Figures 1 and 2 show links in the co-citation matrix and are produced by first reducing all the cocitation values to binary zeros and ones, with the strength of the links added later in the form of line thicknesses. Node positions on the diagrams result from a spring-based algorithm developed by Kamada and Kawai (1989), which iteratively reduces the stress in the graph, from co-locating unconnected nodes together by trying alternative node positions. In our diagrams the frequently cited papers have larger nodes than those less frequently cited, and papers that are often co-cited with each other appear close together and have thicker lines joining them.

Given that our two data sets have many nodes, even if we were to use just the top 50 citations as above, the clarity of the diagrams can be obscured and it makes them difficult to read. Specifically, there is not enough space on the graph to show all the co-citations, and they tend to overlap so extensively that they cannot be distinguished. In producing the networks for the co-citations we found that if we set certain limits on the number of links shown, the number of nodes connected becomes more manageable and the relationships clearer. Thus a limit of, say, at least ten co-citations may be set and a clear diagram produced. It is important to remember that the values represent total co-citation in the relevant database and so if a set limit were to be used, the same level of detail or congestion will not result and the diagrams for one data set may look substantially different from those for another even though the same limit was used in each.

For our diagrams we set the limits to show only links greater than 10 for the North American data and greater than 6 for the Australia/Ireland/NZ/UK set, and then only to show the nodes which are still connected to at least one other node. These levels are useful in that they show the relationships between the central, most highly cited references and also, at these levels, the networks fragment to allow us to talk of groups in much the same way as we did with the factor results.

The figures show much the same story as the factor analysis, with the North American groupings being much denser as they have a larger set of citations in the central focus. As previously discussed, both groups of authors agree on the main literature, concentrated strongly on Barney, and include other contributions to the RBV such as Wernerfelt, Dierickx, Teece, 


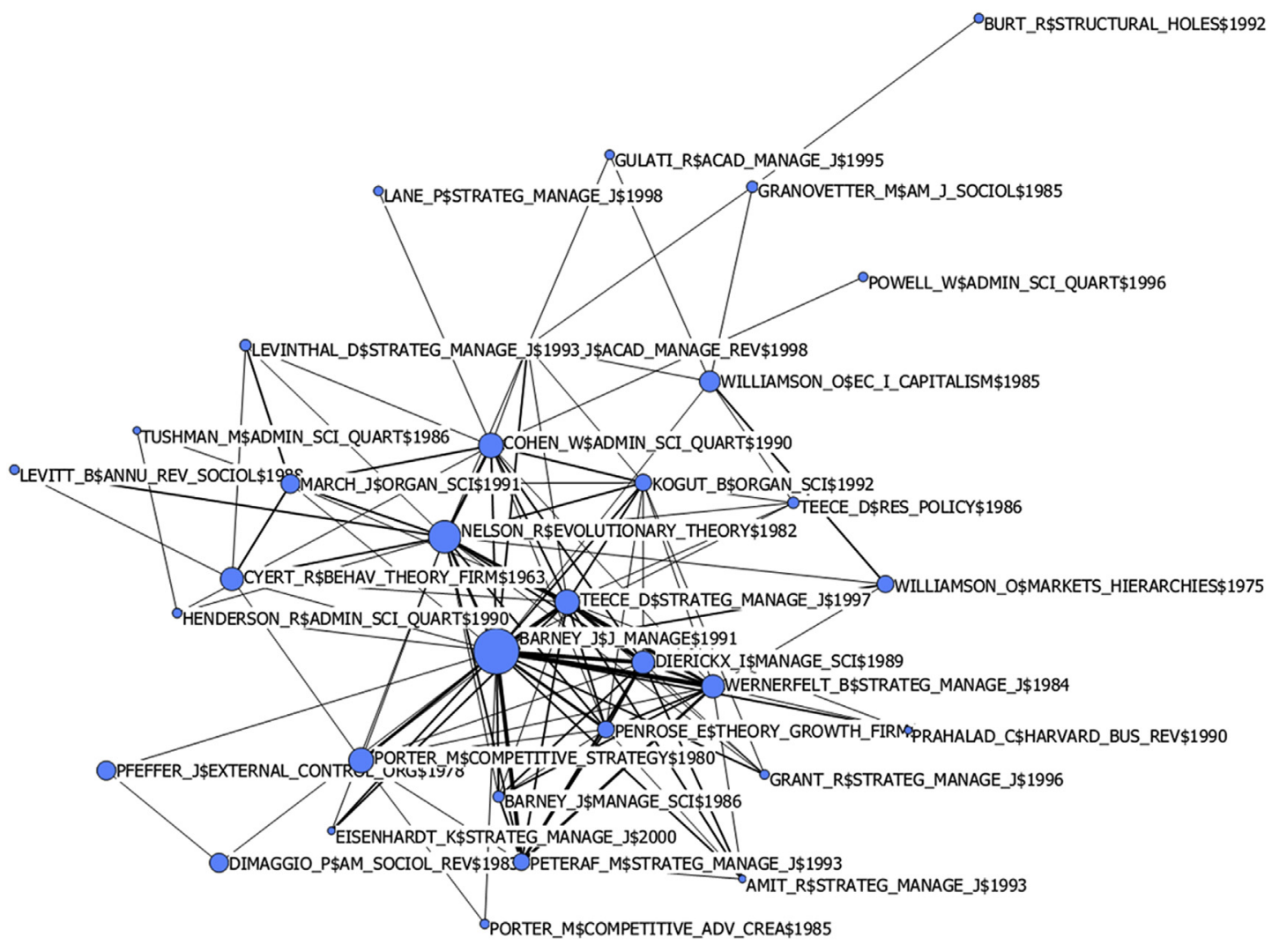

Figure 1. Network graph of the core North American literature.

Penrose and Nelson. This is not surprising, since the RBV is globally accepted as the core theoretical foundation of strategic management research.

The diagrams provide support for the results of the factor analysis as they show many of the same topics but have the added benefit of showing how these relate. This has helped clarify some issues around methodology, and also show the importance of the sociological emphasis of the non-North American journals, whilst stressing the more managerial or positive stance of those based in North America.

\section{Discussion}

The analysis above sought to explore the differences between the North American and Australia/Ireland/NZ/UK authors in terms of their coverage and remit. It is interesting to compare the evolving qualitative descriptions of the field from Figures 1 and 2 with the factor analysis results in Tables 4 and 5. The role of Porter came out clearer in the network approach as we see the differences in justification in North American journals compared to the case based approach of the non-North American outlets. In addition, the Australia/Ireland/NZ/UK co-citations stressed a focus on change and understanding management as its different lenses generate interference patterns whereas the North Americans appears to be more concerned with understanding the different aspects of management as seen in the range and relatively weak overlap between the factor areas above. We see this as an overlaying difference in emphasis of journals like BJM, JMS and LRP on the sociological whilst AMJ, ASQ SMJ and others stress a more managerial or positivist stance. This is clear in the preoccupation of the British tradition with discussing the impact and role of management research itself.

Whilst both sets of authors have a main focus on the RBV, their stances differ significantly. The Australia/Ireland/NZ/UK authors are concerned with changes to resources and the understanding of dynamic capabilities, particularly as organizational phenomena. The North American authors on the other hand are more focused on applied learning and the strategy process of the RBV.

Discussing this in more depth, in identifying the main interest of each set of authors and the groups of references that constitute each topic, one important observation from the factor analysis is the position of the groups. This indicates the most interconnected and easiest to identify dimension. For North Americans, this was more concerned with work group diversity integration into the firm, a topic that is not evident in its non-North American peers. This again illustrates the managerialist stance of the North American publications: what can we learn to improve the management of organizations. In journals like 

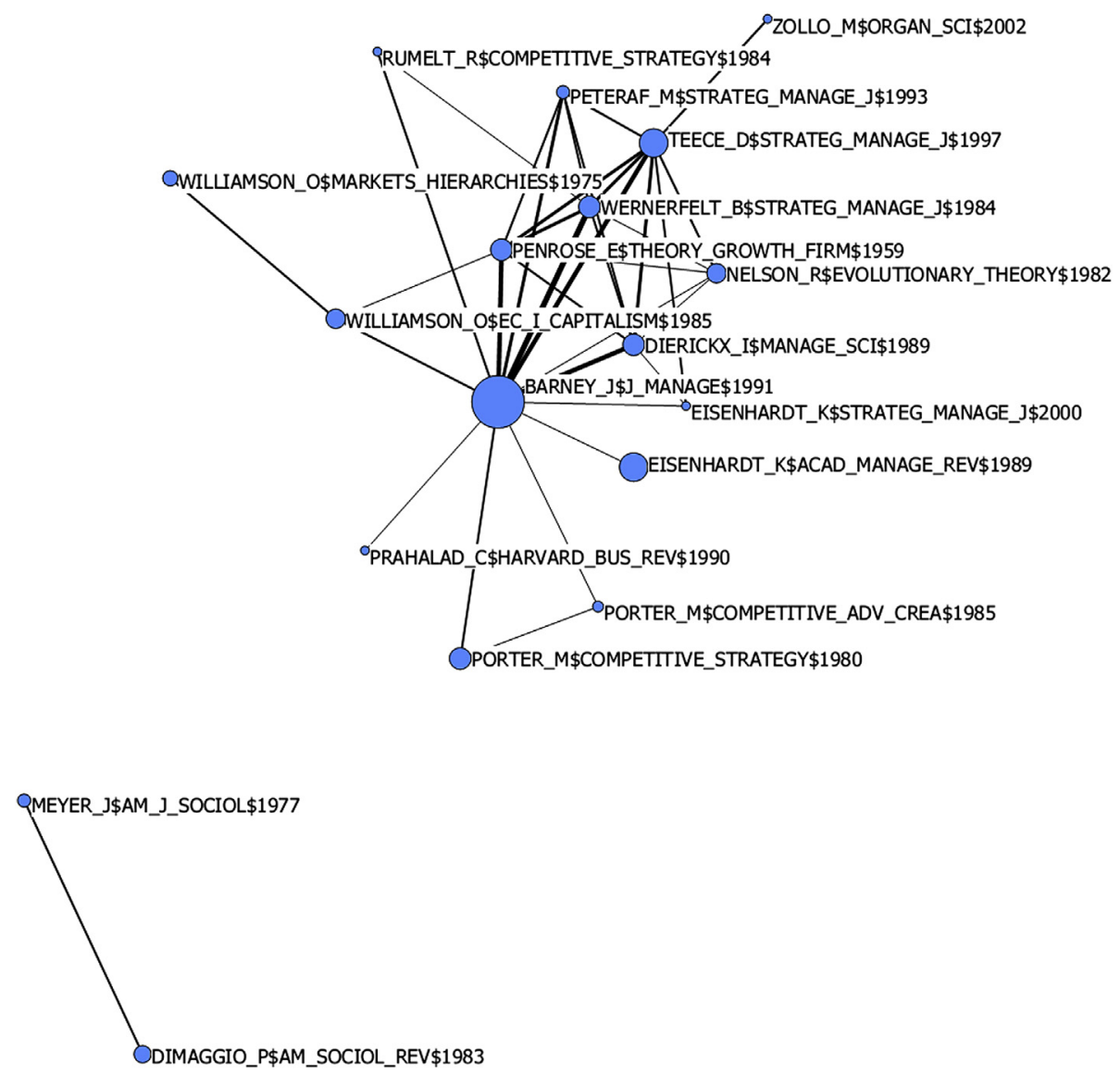

Figure 2. Network graph of the core Australia/Ireland/NZ/UK literature

BJM or JMS, there is more of an approach around how can we dissect the meanings and social interactions in these complex organizations.

The major limitations of this study come from our inability to display the entire intellectual structure of the fields for the two groups of authors publishing in a wide range of journals. For example, being limited to two dimensions rather than the full four or more from the statistical analyses, and the inability to show all the structure because of congestion in the diagrams mean only a portion of the structure can be displayed.

The study is also limited by the references themselves, which are included in the articles. Authors have their own reasons for including particular references in their articles, for example listing those that are believed to be important books in the field even if the author has not read that book or not done so for a long time. Similarly, different journals have different policies and expectations for referencing. We noted earlier the problems of first authors of articles rather than listing all authors. An ISI generated limit is that some data is only available for the last decade and thus we were prevented from exploring the full history of all journals.

Lastly, we have limitations from the data treatment in the study such as the choice of co-citation limits for the diagrams. This affects the positioning and structure of the resulting illustration. We attempted to find cut-offs to show as many citations and links as possible without overcrowding.

\section{Conclusions}

Through analyzing selective publications in strategic management, our study sought to explore the differences in research method and epistemology that exist between North American and non-North American based English language academics. To this end we carried out a citation, co-citation study of leading management and strategy journals based both in North American and internationally. More specifically, we found that the journals showed similar profiles for their referencing and we explored the differences in what they cite. We applied both statistical and qualitative tools to represent the co-citation data, namely principal components analysis and network diagrams.

We found geographical divisions between the journals, with North American authors being the dominant contributors to North American based journals, and the Australia/Ireland/NZ/UK and rest of the world as the major writers of articles for non- 
North American based publications. Also, we noted the limited degree of cross publishing between the groups, with a lack of North American-based authors publishing in BJM and LRP in particular.

The role of methodology came out clearly in the study and benefited greatly from the addition of the network tools. We saw the differences in the quantitative approach of statistically driven regression analysis in North American journals compared to the survey and case based approach of those not based in North America. In addition to the issues around methodology, in general non-North American co-citations stressed a focus on change and understanding management as its different lenses generate interference patterns. In comparison, North American journals appear to be more concerned with understanding and improving the different aspects of management, as seen in the range and relatively weak overlap between the factor areas above. We see this as an overarching difference in emphasis of the non-North American edited journals on the sociological, whilst their North American counterparts stress a more managerial or positivist stance. In the internationally edited journals there is more of an interest in how can we dissect the meanings and social interactions in these complex organizations. Consequently, our work indicates that there is some truth to the rumors that a divide exists between North American and non-North American-based English language scholars in their approaches to general and strategic management research. Strategy is different in North America, both in research methods and design. Further research may reveal whether or not this has any real impact on their respective approaches to strategic management teaching and executive education. The impact implications are likely to be significant, evidenced in a more critical perspective on strategic management practice in countries such as Australia or the UK, and a performance optimizing approach in Canada and the U.S. Further research may reveal how much and in what ways this methodological and epistemological partition has real impact on respective approaches to strategic management teaching, executive development and consulting.

\section{Acknowledgements}

Our thanks to Jonathan Doh, Romano Dyerson, Steven McGuire, Sotirios Paroutis and Roger Strange for their helpful comments on previous versions of this paper. Also, thank you to LRP's anonymous reviewers and to James Robins, Editor-inChief, for their feedback and encouragement.

\section{References}

AoM (Academy of Management), 2013. http://aom.org/memberservices/, (accessed 15.04.13).

Aiken, L.S., West, S.G., 1991. Multiple Regression: Testing and Interpreting Interactions. Sage, London.

Armstrong, J.S., Overton, T.S., 1977. Estimating nonresponse bias in mail surveys. Journal of Marketing Research 14, 396-402.

Ashforth, B.E., Mael, F., 1989. Social identity theory and the organization. Academy of Management Review 14, 20-39.

BAM (British Academy of Management) 2013. Personal communication from BAM council member to the authors, April $18,2013$.

Barney, J., 1991. Firm resources and sustained competitive advantage. Journal of Management 17, 99-120.

Baron, R.M., Kenny, D.A., 1986. The moderator-mediator variable distinction in social psychological research. Conceptual, strategic, and statistical considerations. Journal of Personality and Social Psychology 51, 1173-1182.

Bensman, S.J., 2004. Pearson's r and author cocitation analysis: A commentary on the controversy. Journal of the American Society for Information Science and Technology 55, 935-936.

Blau, P.M., 1977. Inequality and Heterogeneity: A Primitive Theory of Social Structure. Free Press, New York.

Borgatti, S.P., Everett, M.G., Freeman, L.C., 2002. UCINET for Windows: Software for Social Network Analysis. Analytic Technologies, Harvard University.

Burt, R.S., 1992. Structural Holes: The Social Structure of Competition. Harvard University Press, Cambridge, MA.

Child, J., 1972. Organization structure, environment and performance: the role of strategic choice. Sociology 6, 2-22.

Cohen, W.M., Levinthal, D.A., 1990. Absorptive capacity: a new perspective on learning and innovation. Administrative Science Quarterly 35 (1), $128-152$. Culnan, M.J., 1986. The intellectual development of management information systems, 1972-1982: a co-citation analysis. Management Science 32, 156-172.

Cyert, R.M., 1963. A Behavioral Theory of the Firm. Prentice-Hall, Englewood Cliffs, NJ.

Dierickx, I., Cool, K., 1989. Asset stock accumulation and sustainability of competitive advantage. Management Science 35, $1504-1511$.

DiMaggio, P.J., Powell, W.W., 1983. The iron cage revisited: institutional isomorphism and collective rationality in organizational fields. American Sociological Review 48, 147-160.

Eisenhardt, K.M., 1989. Building theories from case study research. Academy of Management Review 14, 532-550.

Eisenhardt, K.M., Martin, J.A., 2000. Dynamic capabilities: what are they? Strategic Management Journal 21, $1105-1121$.

Fama, E.F., Jensen, M.C., 1983. Separation of ownership and control. Journal of Law and Economics 26, $301-325$.

Field, A., 2000. Discovering Statistics Using SPSS for Windows: Advanced Techniques for the Beginner. Sage, London.

Finkelstein, S., 1992. Power in top management teams: dimensions, measurement, and validation. Academy of Management Journal 35, 505-538.

Finkelstein, S., Hambrick, D.C., 1996. Strategic LEADERSHIP: Top Executives and their Effects on Organizations. West Publishing Co., Minneapolis/St. Paul, MN.

Furrer, O., Thomas, H., Goussevskaia, A., 2008. The structure and evolution of the strategic management field: a content analysis of 26 years of strategic management research. International Journal of Management Reviews 10, 1-23.

Garfield, E., 1979. Citation Indexing: Its Theory and Application in Science, Technology, and Humanities. John Wiley \& Sons, New York.

Gibbons, M., 1994. The New Production of Knowledge: Dynamics of Science and Research in Contemporary Societies. Sage, London.

Glaser, B.G., 1967. The Discovery of Grounded Theory: Strategies for Qualitative Research. Aldine de Gruyte, New York.

Granovetter, M., 2005. The impact of social structure on economic outcomes. The Journal of Economic Perspectives 19 (1), $33-50$.

Gulati, R., 1998. Alliances and networks. Strategic Management Journal 19 (4), 293-317.

Hair, J.F., 1995. Multivariate Data Analysis: With Readings, fourth ed. Prentice Hall, Englewood Cliffs, NJ.

Hansen, M.T., 1999. The search-transfer problem: the role of weak ties in sharing knowledge across organization subunits. Administrative Science Quarterly 44 (1), 82-111.

Haslam, S.A., Postmes, T., Ellemers, N., 2003. More than a metaphor: organizational identity makes organizational life possible. British Journal of Management 14, 357-369.

Helfat, C.E., Peteraf, M.A., 2003. The dynamic resource-based view: capability lifecycles. Strategic Management Journal 24, $997-1010$.

Hodgkinson, G.P., Herriot, P., Anderson, N., 2001. Re-aligning the stakeholders in management research: lessons from industrial, work and organizational psychology. British Journal of Management 12, S41-S48. 
Hoffman, D.L., Holbrook, M.B., 1993. The intellectual structure of consumer research: a Bibliometric study of author cocitations in the first 15 years of the journal of consumer research. Journal of Consumer Research 19, 505-517.

Huber, G.P., 1991. Organizational learning: the contributing processes and the literatures. Organization Science 2, 88-115.

Huff, A.S., 2000. 1999 Presidential address: changes in organizational knowledge production. Academy of Management Review 25, $288-293$.

Jensen, M.C., Meckling, W.H., 1976. Theory of the firm: managerial behavior, agency costs and ownership structure. Journal of Financial Economics 3 , 305-360.

Kamada, T., Kawai, S., 1989. An algorithm for drawing general undirected graphs. Information Processing Letters 31, 7-15.

Kogut, B., Zander, U., 1993. Knowledge of the firm and the evolutionary theory of the multinational corporation. Journal of International Business Studies 24 (4), 625-645.

Leong, S.M., 1989. A citation analysis of the journal of consumer research. The Journal of Consumer Research 15, 492-497.

Levinthal, D.A., March, J.G., 1993. The myopia of learning. Strategic Management Journal 14, 95-112.

Levitt, B., March, J.G., 1988. Organizational learning. Annual Review of Sociology 14, 319-338.

Leydesdorff, L., 1987. Various methods for the mapping of science. Scientometrics 11, 295-324.

Leydesdorff, L., Vaughan, L., 2006. Co-occurrence matrices and their applications in information science: extending ACA to the web environment. Journal of the American Society for Information Science and Technology 57, 1616-1628.

March, J.G., 1991. Exploration and exploitation in organizational learning. Organization Science 2, 71-87.

Meyer, J.W., Boli, J., Thomas, G.M., Ramirez, F.O., 1997. World Society and the Nation-State. American Journal of Sociology 103, $144-181$.

Miles, M.B., Huberman, A.M., 1994. Qualitative Data Analysis: An Expanded Sourcebook, second ed. Sage, Thousand Oaks, CA/London.

Milliken, F.J., Martins, L.L., 1996. Searching for common threads: understanding the multiple effects of diversity in organizational groups. Academy of Management Review 21, 402-433.

Nahapiet, J., Ghoshal, S., 1998. Social capital, intellectual capital, and the organizational advantage. Academy of Management Review 23 (2), $242-266$.

Nonaka, I., 1995. The Knowledge-Creating Company. Oxford University Press, New York/Oxford.

Pelled, L.H., Eisenhardt, K.M., Xin, K.R., 1999. Exploring the black box: an analysis of work group diversity, conflict, and performance. Administrative Science Quarterly 44,1-28.

Pettigrew, A.M., 1992. On studying managerial elites. Strategic Management Journal 13, 163-182.

Pettigrew, A.M., Whipp, R., 1991. Managing Change for Competitive Success. Blackwell, Oxford.

Pilkington, A., Chai, K., 2008. Research themes, concepts and relationships: a study of International Journal of Service Industry Management (1990-2005). International Journal of Service Industry Management 19, 83-110.

Pilkington, A., Liston-Heyes, C., 1999. Is production and operations management a discipline? A citation/co-citation study. International Journal of Operations and Production Management 19, 7-20.

Pilkington, A., Meredith, J., 2009. The evolution of the intellectual structure of operations management - 1980-2006: a citation/co-citation analysis. Journal of Operations Management 27, 185-202.

Pilkington, A., Teichert, T., 2006. Management of technology: themes, concepts and relationships. Technovation 26, 288-299.

Podsakoff, P.M., Organ, D.W., 1986. Self-reports in organizational research: problems and prospects. Journal of Management 12 (4), 531.

Porter, M.E., 1985. Competitive Advantage: Creating and Sustaining Superior Performance. Free Press, New York.

Porter, M.E., 1980. Competitive Strategy: Techniques for Analyzing Industries and Competitors. Free Press, New York.

Powell, W.W., Koput, K.W., Smith-Doerr, L., 1996. Interorganizational collaboration and the locus of innovation: Networks of learning in biotechnology. Administrative Science Quarterly 41, 116-145.

Ramos-Rodríguez, A., Ruíz-Navarro, J., 2004. Changes in the intellectual structure of strategic management research: a bibliometric study of the Strategic Management Journal, 1980-2000. Strategic Management Journal 25, 981-1004.

Roberts, J., McNulty, T., Stiles, P., 2005. Beyond agency conceptions of the work of the non-executive director: creating accountability in the boardroom. British Journal of Management 16, 5-26.

Scott, W.R., 1995. Institutions and Organizations: Theory and Research. Sage, London.

Senge, P.M., 1990. The Fifth Discipline: The Art \& Practice of the Learning Organization. Doubleday/Currency, New York/London.

Sharplin, A.D., Mabry, R.H., 1985. The relative importance of journals used in management research: an alternative ranking. Human Relations 38, 139-149.

Small, H., 1973. Co-citation in the scientific literature: a new measure of the relationship between two documents. Journal of the American Society for Information Science 24, 265-269.

Starkey, K., Madan, P., 2001. Bridging the relevance gap: aligning stakeholders in the future of management research. British Journal of Management 12 , S3-S26.

Strauss, A.L., 1990. Basics of Qualitative Research: Grounded Theory Procedures and Techniques. Sage, Newbury Park, CA.

Stremersch, S., Verniers, I., Verhoef, P.C., 2007. The quest for citations: drivers of article impact. Journal of Marketing 71 (3), $171-193$.

Szulanski, G., 1996. Exploring internal stickiness: Impediments to the transfer of best practice within the firm. Strategic Management Journal 17, $27-43$.

Tranfield, D., Starkey, K., 1998. The nature, social organization and promotion of management research: towards policy. British Journal of Management 9 (4), $341-353$.

Tsui, A.S., Egan, T.D., O'Reilly, C.A., 1992. Being different: relational demography and organizational attachment. Administrative Science Quarterly 37 (4), 412-438.

Turner, J.C., 1987. Rediscovering the Social Group: A Self-Categorization Theory. Blackwell, Oxford/New York.

Usdiken, B., Pasadeos, Y., 1995. Organizational analysis in North America and Europe: a comparison of co-citation networks. Organization Studies 16, 503-526.

Vokurka, R.J., 1996. The relative importance of journals used in operations management research: a citation analysis. Journal of Operations Management 14 (4), 345-355.

Wasserman, S., 1994. Social Network Analysis: Methods and Applications. Cambridge University Press, Cambridge.

Weick, K.E., 1995. Sensemaking in Organizations. Sage, Thousand Oaks, CA/London.

Wernerfelt, B., 1984. A resource-based view of the firm. Strategic Management Journal 5 (2), 171-180.

White, H.D., 1990. Author co-citation analysis: overview and defense. Scholarly Communication and Bibliometrics 84, 106.

White, H.D., McCain, K.W., 1998. Visualizing a discipline: an author co-citation analysis of information science, 1972-1995. Journal of the American Society for Information Science 49, 327-355.

Williamson, O.E., 1975. Markets and Hierarchies, Analysis and Antitrust Implications: A Study in the Economics of Internal Organization. Free Press, New York.

Yin, R.K., 1994. Case Study Research: Design and Methods, second revised ed. Sage, Thousand Oaks, CA.

Zollo, M., Winter, S.G., 2002. Deliberate learning and the evolution of dynamic capabilities. Organization Science 13 (3), 339-351.

\section{Biographies}

Prof. Alan Pilkington is Professor of Operations Management at Copenhagen Business School and Adjunct Professor at Hult International Business School. He is a Chartered Engineer and Chair of the IEEE Technology Management Council UKRI Chapter, a senior member of the IEEE, a member of the IET, European Operations Management Association, Academy of Management and POMS. He has numerous publications, including articles in the California Management Review, Journal of Operations Management, Technovation, and International Journal of Operations and Production Management. Email: a.pilkington@rhul.ac.uk 
Prof. Thomas C. Lawton is Professor of Strategy and International Management at the Open University Business School and Director of the Centre for International Management Practice. He is also a Visiting Professor at the Tuck School of Business at Dartmouth. He is a Fellow of the Royal Society of Arts and the Strategic Planning Society. An experienced executive educator and management consultant, he has authored or edited seven books, and has published in journals including Academy of Management Perspectives, International Business Review, International Journal of Management Reviews, and Management International Review. Email: thomas.lawton@open.ac.uk 